Hart, E. B., Miller, W. S. \& McCollum, E. V. (1916). F. biol. Chem. 25, 239.

Helmboldt, C. F., Jungherr, E. L., Eaton, H. D. \& Moore, L. A. (r953). Amer. F. vet. Res. r4, 343.

Lamming, G. E., Woollam, D. H. M. \& Millen, J. W. (1954). Brit. F. Nutr. 8, ${ }^{6}{ }_{3}$.

Marie, J. \& Sée, G. (1954). Amer. F. Dis. Child. 87, 731 .

Mellanby, E. (1938-9). F. Physiol. 94, 380.

Mellanby, E. (1940-1). F. Physiol. 99, 467.

Millen, J. W. \& Woollam, D. H. M. (1956). F. Neurol. Psychiat. 19, 17.

Millen, J. W., Woollam, D. H. M. \& Lamming, G. E. (1954). Lancet, 267, 679.

Moore, L. A. \& Sykes, J. F. (1940). Amer. F. Physiol. r3o, 684.

Sorensen, D. K., Kowalczyk, T. \& Hentges, J. F. Jr. (1954). Amer. F. vet. Res. 15, 258.

Wolbach, S. B. \& Bessey, O. A. (194I). Arch. Path. (Lab. Med.) 32, 689.

Woollam, D. H. M. \& Millen, J. W. (1956). Brit. F. Nutr. 1o, 355.

\title{
The content of amino-acids in white flour and bread
}

\author{
By E. E. McDERMOTT ANd J. PACE \\ Research Association of British Flour-Millers, Cereals Research Station: \\ Old London Road, St Albans
}

(Received 12 Fune 1957)

Wheaten flour and bread provided, in $1955,27.8 \%$ of the total protein consumed in this country (Ministry of Agriculture, Fisheries and Food: National Food Survey Committee, 1957). Yet the information available on the amino-acid composition of such important sources of dietary protein is surprisingly inadequate. Thus at the present time no complete quantitative analysis of the amino-acids contained in the bread consumed in this country is available in the literature. Data given by Block \& Bolling (1945) are incomplete and refer to bread made in the U.S.A. For flour the position is better than with bread but is still unsatisfactory. Stokes, Gunness, Dwyer \& Caswell (1945) have analysed a patent flour, prepared in the U.S.A., for ten aminoacids including those essential for the growing rat. Baumgartner, Mather \& Stone (1946) have reported incomplete figures for whole wheat, milling fractions and an uncharacterized flour. Block \& Mitchell (1946-7) have given the content of thirteen amino-acids in whole wheat and gluten, and Barton-Wright \& Moran (1946) have determined the content of the essential amino-acids in whole wheat and in various fractions of the grain. Complete analyses have been reported more recently, by Kraut, Kofrányi, Telschow $\&$ Weber (I955), but these refer to two German flours with the relatively low nitrogen contents of $1 \cdot 42$ and $1.56 \%$.

The inadequacy of the data available to workers concerned with human nutrition has been emphasized by Hughes (1955) in reporting his calculations of the essential amino-acids available in the diets of the German children who took part in the experiments described in the report of Widdowson \& McCance (1954). For the figures for white bread he was obliged, in the absence of more relevant information at that time, to use the data of Stokes et al. (1945), obtained for a patent (U.S.A.) flour. This experience also illustrates the paucity of information on the effect, upon the total 
amino-acid composition, of transforming a given flour into bread, although the effect of this process upon one amino-acid constituent, lysine, has been studied by Rosenberg \& Rohdenburg (I95 $\mathrm{r}$ ) with conditions of bread-making usual in the U.S.A.

The experiments described below have been carried out to provide some of the additional information which is needed. The content of amino-acids in a white flour, prepared from a typical commercial grist, has been measured by a modification of the ion-exchange chromatography of Moore \& Stein (I95 I, I954). Bread was made from this flour and its content of amino-acids then determined by the same technique.

\section{EXPERIMENTAL}

\section{Materials}

Flour. A sample of the mixed grist used at a commercial mill for the production of baker's flour was obtained. The white flour, of $66 \%$ extraction rate, was milled from this grist in the laboratory. The nitrogen content of the flour, expressed on a dry, ash-free basis, was $2 \cdot 28 \%$. The ash content, expressed on a moisture-free basis, was $0.53 \%$.

Bread. Small loaves of the type used in test baking were made, which made it possible to freeze-dry a whole loaf so that true samples of the whole loaf, including crust, could be taken for analysis. The dough (for a single loaf) was prepared from I $40 \mathrm{~g}$ flour, $2 \mathrm{~g}$ yeast and $74.5 \mathrm{ml}$. of a $2.5 \%$ solution of sodium chloride. The bread was baked in an oven at $425^{\circ} \mathrm{F}$. for $24 \mathrm{~min}$. After cooling, the loaves were sliced and the slices freeze-dried. The dried crumb was then finely powdered. The nitrogen content of the crumb, expressed on a moisture- and ash-free basis, was $2 \cdot 37 \%$.

Ion-exchange resin. The resin used was Zeo-Karb 225, (Permutit Co. Ltd, London), 200-400 mesh, with $12 \%$ cross-linkage. In a detailed study with gliadin as a test protein, which will be submitted for publication elsewhere, various resins and operating conditions have been tested for their suitability and convenience for use with wheat proteins. These present a special problem because of the relatively high content of glutamic acid and proline. The resin was cleaned and prepared for use according to the instructions of Moore \& Stein (195I).

\section{Hydrolysates}

\section{Methods}

Samples of flour and bread crumb (about I g) were hydrolysed by boiling under reflux with $6 \mathrm{~N}-\mathrm{HCl}(200 \mathrm{ml}$.) for $20 \mathrm{~h}$. Excess $\mathrm{HCl}$ was removed by repeated evaporation under reduced pressure and insoluble humin was removed by filtration. The filtrate was then taken down to small volume under reduced pressure and made up to $25 \mathrm{ml}$. with $0 . \mathrm{I} \mathrm{M}$ citrate buffer, $\mathrm{pH} 2 \cdot 2$. Usually $\mathrm{I} \mathrm{ml}$. of this solution was used for the main analysis and $2 \mathrm{ml}$. for determination of the basic amino-acids.

\section{Separation of amino-acids on the ion-exchange resin}

Acidic and neutral amino-acids. The methods described by Moore \& Stein (195 I) and used by Eastoe (1955) were employed with some modification. For separation of 
the acidic and neutral amino-acids the sample was washed on to the column $(100 \mathrm{~cm})$ with I ml. of $\mathrm{O} \cdot \mathrm{I} \mathrm{M}$ citrate buffer, $\mathrm{pH} 2 \cdot 2$, and the temperature maintained at $37.5^{\circ}$ for the whole run. Elution was begun with $0^{\circ} \mathrm{I} \mathrm{M}$ citrate buffer, $\mathrm{pH} 3 \cdot 42$, until the emergence of the valine peak, when the buffer was changed to $0 . \mathrm{m}$ M citrate buffer, $\mathrm{pH} 5.0$ (cf. Moore \& Stein, 1954), and elution with this buffer continued until after the emergence of the phenylalanine peak.

These modifications of the techniques of Moore \& Stein were adopted, after preliminary experiments in which we found that (I) using the technique of Moore \& Stein (1954) with the only sample of Dowex 50 at our disposal we obtained no resolution of glutamic acid and proline, (2) with the same technique but with the resin Zeo-Karb 225 glutamic acid and proline were well resolved but there was poor resolution of threonine and serine and the tyrosine and phenylalanine peaks were very broad. With the modified procedure glutamic acid and proline were well separated, there was good resolution of threonine and serine and sharper peaks for tyrosine and phenylalanine were obtained.

Both buffers contained thiodiglycol, benzyl alcohol and BRIJ 35 (Honeywill and Stein Ltd, London) in the proportions given by Moore \& Stein (I95I). With these conditions the sequence in which amino-acids emerge from the column is the same as that observed by Moore \& Stein (I95I), except that the cystine peak appears between those of proline and glycine, and sometimes overlaps glycine. The cystine value was not computed from this peak but a separate determination was made in which cystine was estimated as cysteic acid. For this purpose flour or bread crumb (about I g) was oxidized with performic acid, as described by Schram, Moore \& Bigwood (1954). After concentration under reduced pressure in a rotary evaporator the oxidized material was hydrolysed, as described above, and a sample applied to a $100 \mathrm{~cm} \mathrm{Zeo-Karb} 225$ column in the usual way. On eluting with $\circ \cdot 1 \mathrm{M}$ citrate buffer, $\mathrm{pH} 3 \cdot 42$, the first peak to emerge was cysteic acid. Usually collection of effluent from this column was continued until the glycine peak had emerged. The glycine value was computed from this peak since, as noted above, it was sometimes overlapped on the other column by cystine.

Basic amino-acids. These were determined on a $2 \mathrm{ml}$. sample of hydrolysate, by elution from a $15 \mathrm{~cm}$ column of Zeo-Karb 225 by the general procedure of Moore \& Stein (195I). One modification was made; instead of the $\mathrm{pH} 6.8$ buffer of Moore \& Stein one of $\mathrm{pH} 6.9$ was used, which under our conditions gave a better separation of histidine from lysine.

\section{Determination of amino-acids}

The amino-acids were determined colorimetrically with the ninhydrin reagent of Moore \& Stein (1948); the experimental conditions used for the development of colour were those of Moore \& Stein (195I), with I ml. ninhydrin reagent and a heating time of $30 \mathrm{~min}$.

Tryptophan. Tryptophan was determined microbiologically, by the hydrolysis technique of Kuiken, Lyman \& Hale (1947) and assay with Lactobacillis casei (Clegg, Kodicek \& Mistry, 195 I-2), but the results with extracts of flour and bread were not 
reproducible. The colorimetric method of Graham Smith, Hier \& Klein (I947) gave consistent results for flour. With bread the colorimetric determination was complicated by the production of an interfering colour of reddish hue. The significance of this observation has not yet been evaluated and therefore only the tryptophan value obtained for flour is reported in this paper.

\section{RESULTS}

The results obtained with hydrolysates of flour and bread are given in Table 1 . The values are means of two determinations. Values for duplicate determinations on wheatprotein hydrolysates in our experience generally show a reproducibility better than $\pm 4 \%$ for all amino-acids other than methionine, which is in agreement with the experience of Eastoe (1955) who used a similar technique with gelatin hydrolysates. Values for amino-acids present in amounts less than $5 \%$ have been given to two decimal places. There is no implication that the second place is accurately known but, following Eastoe (1955), it is regarded as an indication for comparative purposes.

Table 1. Content of amino-acids in hydrolysates of flour and bread

\begin{tabular}{|c|c|c|c|c|}
\hline \multirow[b]{2}{*}{ Amino-acid } & \multicolumn{2}{|c|}{$\begin{array}{l}\text { Amino-acid nitrogen } \\
(\mathrm{g} / \mathrm{I} 00 \mathrm{~g} \text { total } \mathrm{N})\end{array}$} & \multicolumn{2}{|c|}{$\begin{array}{c}\text { Amino-acid } \\
\text { (g/roo g dry weight) }\end{array}$} \\
\hline & Flour & Bread & Flour & Bread \\
\hline Alanine & 2.87 & $2 \cdot 93$ & $0.4 I$ & 0.43 \\
\hline Arginine & $6 \cdot 72$ & $6 \cdot 71$ & 0.47 & 0.48 \\
\hline Aspartic acid & $2 \cdot 66$ & $2 \cdot 72$ & 0.57 & 0.60 \\
\hline Cystine & $\mathrm{I} \cdot 68$ & $I \cdot 64$ & 0.32 & 0.32 \\
\hline Glutamic acid & 19.94 & $19 \cdot 56$ & $4 \cdot 60$ & $4 \cdot 61$ \\
\hline Glycine & 3.93 & 3.97 & 0.48 & 0.49 \\
\hline Histidine & 3.59 & 3.52 & 0.30 & 0.30 \\
\hline Isoleucine & $2 \cdot 55$ & $2 \cdot 49$ & 0.54 & 0.54 \\
\hline Leucine & $4 \cdot 81$ & $4 \cdot 89$ & $\mathrm{I} \cdot 02$ & $I \cdot 06$ \\
\hline Lysine & $2 \cdot 36$ & $2 \cdot 29$ & 0.28 & 0.28 \\
\hline Methionine & $I \cdot 05$ & $I \cdot I I$ & 0.25 & 0.28 \\
\hline Phenylalanine & $2 \cdot 80$ & $2 \cdot 61$ & 0.75 & 0.71 \\
\hline Proline & $8 \cdot 83$ & $8 \cdot 80$ & $x \cdot 64$ & $I \cdot 67$ \\
\hline Serine & 3.89 & 3.67 & 0.66 & 0.64 \\
\hline Threonine & $2 \cdot 05$ & 2.07 & 0.39 & 0.41 \\
\hline Tryptophan & 0.08 & $\ldots$ & - & - \\
\hline Tyrosine & $I \cdot 6 I$ & $I \cdot 51$ & 0.47 & 0.45 \\
\hline Valine & $3 \cdot 28$ & $3 \cdot 14$ & 0.62 & $0.6 \mathrm{I}$ \\
\hline
\end{tabular}

In the baking process destruction of amino-acids is most likely to occur in the crust of the bread. The small loaves used in these experiments had a higher surface: volume ratio than a loaf of ordinary size so that any destructive effect on the crust occurring in commercial bread would, presumably, not be underestimated in the values given here. Since any effect would be at a maximum in the crust, it was hydrolysed separately and analysed. The hardened outer skin of crust was used which amounted to $18.4 \%$ of the weight of the loaf. The values obtained are given in Table 2. 
Table 2. Content of amino-acids in hydrolysed bread crust

\begin{tabular}{|c|c|c|}
\hline Amino-acid & $\begin{array}{l}\text { Amino-acid nitrogen } \\
(\mathrm{g} / \mathrm{L} \text { - } \mathrm{g} \text { total } \mathrm{N})\end{array}$ & $\begin{array}{c}\text { Amino-acid } \\
\text { (g/10o g dry crust) }\end{array}$ \\
\hline Alanine & $2 \cdot 93$ & 0.42 \\
\hline Arginine & $6 \cdot 68$ & 0.47 \\
\hline Aspartic acid & $2 \cdot 55$ & 0.55 \\
\hline Glutamic acid & 18.84 & $4 \cdot 4^{8}$ \\
\hline Histidine & $3 \cdot 5^{8}$ & 0.30 \\
\hline Isoleucine & $2 \cdot 4 \mathrm{I}$ & 0.51 \\
\hline Leucine & $4 \cdot 70$ & $r \cdot 00$ \\
\hline Lysine & $2 \cdot 04$ & 0.24 \\
\hline Methionine & $x \cdot 04$ & 0.24 \\
\hline Phenylalanine & $2 \cdot 34$ & 0.63 \\
\hline Proline & $8 \cdot 36$ & I. 56 \\
\hline Serine & 3.57 & 0.61 \\
\hline Threonine & $2 \cdot 04$ & 0.39 \\
\hline Tyrosine & $r \cdot 34$ & 0.39 \\
\hline Valine & 3.02 & 0.57 \\
\hline
\end{tabular}

DISCUSSION

Inspection of the values in columns 2 and 3 of Table 1 shows that hydrolysates of the bread and flour used in these experiments had a closely similar amino-acid composition. The values found for phenylalanine, tyrosine and serine in the bread hydrolysate were 5-7\% lower than the corresponding figures for the flour hydrolysate, and this reduction is more than can be accounted for by the experimental error of $\pm 4 \%$. Yet the overall close correspondence of the figures for the two hydrolysates is a more striking feature of the values than these slight differences. It does not necessarily follow that these small differences are due to losses incurred during the baking process. They may be a consequence of the hydrolysis procedure where the conditions, prolonged heating in the presence of carbohydrate, are more severe and potentially more liable to cause destruction of susceptible amino-acids than those of the baking process itself. It is also possible that losses during the hydrolysis of bread may be slightly different from those occurring during the hydrolysis of flour. This possibility introduces some uncertainty in interpretation but it may be concluded ( $\mathrm{I}$ ) that judged by the hydrolysates, differences in amino-acid composition between the flour and the bread are of minor importance nutritionally, as may be seen from inspection of columns 4 and 5 of Table $I ;(2)$ that the values given in Table I will tend slightly to underestimate the content in the intact protein of those amino-acids susceptible to destruction by prolonged heating in the presence of carbohydrate. At the same time it should be noted that if the biological availability of lysine, for example, has been reduced by bond formation at the $\epsilon-\mathrm{NH}_{2}$ group this will not necessarily be shown by analysis of the hydrolysates since the bond formed, which is resistant to the action of digestive enzymes, may be broken by acid, and the amino-acid regenerated.

The most noteworthy feature of the values for the crust hydrolysate, when compared with those obtained for the whole crumb are the more pronounced losses of phenylalanine and tyrosine, and a significant loss of lysine. The content of these three amino-acids in the crust hydrolysate is some $15^{-1} 6 \%$ less than in the flour hydrolysate. As the change in the content of these three amino-acids, when crust is compared with 
crumb, is so much more pronounced than it is, for example, with serine, it may be considered as evidence that they are directly implicated in destructive reactions taking place during the formation of the crust. This appears to be a reasonable deduction but it cannot be established unequivocally because of effects, referred to previously, which may possibly be induced during hydrolysis.

Rosenberg \& Rohdenburg (I95I) have reported a significant loss of lysine when dough is baked into bread, and their data also indicate that the same occurs in the crust. As their determinations were made with hydrolysates there is the same uncertainty in interpretation as in the work described in this paper.

It is now possible to calculate approximately, from the figures given in this paper, the daily intake of essential amino-acids provided by the flour and bread consumed in this country, taking the average consumption for all households for the year $\mathbf{1 9 5 5}$. According to the Ministry of Agriculture, Fisheries and Food: National Food Survey Committee (1957) the average daily intake of calories per head was $264 \mathrm{I} \mathrm{Cal}$., and flour and bread provided $26.5 \%$ of this energy intake. That is, bread and flour provided daily $700 \mathrm{Cal}$. per head, equivalent to an intake of $170 \mathrm{~g}$ flour on the dryweight basis. The approximate amount of each of the essential amino-acids provided by this quantity of flour is given in the second column of Table 3 . In the third column are given the minimum daily amounts of each amino-acid required to maintain adult human subjects in nitrogen equilibrium (Rose, Wixom, Lockhart \& Lambert, r955).

\section{Table 3. Essential amino-acids provided by flour and bread}

\begin{tabular}{|c|c|c|}
\hline Amino-acid & $\begin{array}{l}\text { Quantity per head of } \\
\text { amino-acid provided } \\
\text { by average daily intake } \\
\text { of flour and bread* }\end{array}$ & $\begin{array}{l}\text { Minimum daily } \\
\text { requirement } \\
\text { (Rose et al. 1955) }\end{array}$ \\
\hline Valine & 1.07 & 0.8 \\
\hline Leucine & $x \cdot 75$ & $I \cdot I$ \\
\hline Isoleucine & 0.93 & 0.7 \\
\hline Threonine & 0.68 & 0.5 \\
\hline Phenylalanine & $1 \cdot 29$ & $\mathbf{I} \cdot \mathbf{I}$ \\
\hline Lysine & 0.48 & 0.8 \\
\hline Tryptophan & 0.27 & 0.25 \\
\hline Methionine & 0.44 & $I \cdot I$ \\
\hline $\begin{array}{l}\text { Methionine+ } \\
\text { cystine }\end{array}$ & $I \cdot O I$ & - \\
\hline
\end{tabular}

* Calculated from our results and statistics of the Ministry of Agriculture, Fisheries and Food: National Food Survey Committee (1957).

It may be concluded, from the values given in Table 3 , that the average daily consumption of flour and bread supplied five of the essential amino-acids (valine, leucine, isoleucine, phenylalanine, threonine) in excess of the minimum requirement suggested by Rose et al. (1955). The lysine contributed by flour and bread was well below the minimum requirement and tryptophan was at about the minimum level. Methionine considered by itself was also below the minimum requirement. Even if the observation of Rose et al. (1955) that in the presence of cystine there is a sparing effect of $80-89 \%$ is taken into account, the level of methionine together with cystine was still below the minimum requirement. 
SUMMARY

I. The content of amino-acids in hydrolysates $(a)$ of white flour, $(b)$ of bread made from that flour, and $(c)$ of the crust of the bread has been determined by ion-exchange chromatography.

2. The contents of phenylalanine, tyrosine and serine in the bread hydrolysate were each lower, to the extent of about $5-7 \%$, than in the flour hydrolysate. No significant differences, between the two hydrolysates, were observed in the content of other amino-acids.

3. More pronounced losses were observed in the crust hydrolysate, notably in the content of phenylalanine, tyrosine and lysine. The content of each of these three amino-acids was $15-16 \%$ less in the crust hydrolysate than in the flour hydrolysate.

4. In discussing the significance of these losses attention is drawn to the difficulty of establishing unequivocally how far they may be due to the baking process itself and how far to destructive action during hydrolysis, which may vary from flour to crust.

5. The approximate quantity of each of the essential amino-acids provided by the average daily consumption of flour and bread per head of the population of this country has been calculated.

We are grateful to Dr K. M. Clegg for carrying out the tryptophan assays.

\section{REFERENCES}

Barton-Wright, E. C. \& Moran, T. (1946). Analyst, 7x, 278.

Baumgartner, W., Mather, A. N. \& Stone, L. (i 946), Cereal Chem. 23, I35.

Block, R. J. \& Bolling, D. (1945). The Amino Acid Composition of Proteins and Foods, Ist ed. Springfield, III.: C. C. Thomas.

Block, R. J. \& Mitchell, H. H. (1946-7). Nutr. Abstr. Rev. 16, 249.

Clegg, K. M., Kodicek, E. \& Mistry, S. P. (1951-2). Biochem. F. 50, 326.

Eastoe, J. E. (1955). Biochem. F. 6r, 589.

Graham, C. E., Smith, E. P., Hier, S. W. \& Klein, D. (1947). F. biol. Chem. 168, 7 I1.

Hughes, B. P. (1955). Brit. F. Nutr. 9, 373.

Kraut, H., Kofrányi, E., Telschow, H. \& Weber, M. (1955). Hoppe-Seyl. Z. 3or, I65.

Kuiken, K. A., Lyman, C. M. \& Hale, F. (1947). F. biol. Chem. 171, 55 I.

Ministry of Agriculture, Fisheries and Food: National Food Survey Committee (1957). Domestic Food Consumption and Expenditure, 1955. London: H.M. Stationery Office.

Moore, S. \& Stein, W. H. (r948). F. biol. Chem. 176, 367.

Moore, S. \& Stein, W. H. (1951). F. biol. Chem. 192, 663 .

Moore, S. \& Stein, W. H. (1954). F. biol. Chem. 21 1893 .

Rose, W. C., Wixom, R. L., Lockhart, H. B. \& Lambert, G. F. (1955). F. biol. Chem. $217,987$.

Rosenberg, H. R. \& Rohdenburg, E. L. (I95I). F. Nutr. 45, 593.

Schram, E., Moore, S. \& Bigwood, E. J. (1954). Biochem. F. 57, 33.

Stokes, J. L., Gunness, M., Dwyer, I. M. \& Caswell, M. C. (1945). F. biol. Chem. 16o, 35.

Widdowson, E. M. \& McCance, R. A. (I954). Spec. Rep. Ser. med. Res. Coun., Lond., no. 287. 